\title{
Effect of a CNS-Sensitive Anticholinesterase Methane Sulfonyl Fluoride on Hippocampal Acetylcholine Release in Freely Moving Rats
}

\author{
Tamotsu Imanishi, ${ }^{1,2}$ Muhammad Mubarak Hossain,, 3 Tadahiko Suzuki, ${ }^{1}$ Ping Xu, ${ }^{1,4}$ \\ Itaru Sato, ${ }^{1}$ and Haruo Kobayashi ${ }^{1,5}$ \\ ${ }^{1}$ Department of Veterinary Medicine, Faculty of Agriculture, Iwate University, Ueda, Morioka 020-8550, Japan \\ ${ }^{2}$ Department of Food Safety, Pharmaceutical and Medical Safety Bureau, Ministry of Health, Labour and Welfare, Kasumigaseki, \\ Chiyoda, Tokyo 100-8916, Japan \\ ${ }^{3}$ Department of Environmental and Occupational Medicine, Robert Wood Johnson Medical School, \\ University of Medicine and Dentistry of New Jersey, 170 Frelinghuysen Road, Piscataway, NJ 08854, USA \\ ${ }^{4}$ Sciences of Cryobiosystems, United Graduate School of Agricultural Sciences of Iwate University, Ueda, Morioka 020-8550, Japan \\ ${ }^{5}$ 7-272 Aza-Mukaishinden, Ukai, Takizawa-mura, Iwate-gun, Iwate Prefecture 020-0172, Japan
}

Correspondence should be addressed to Haruo Kobayashi, yhkoba@ictnet.ne.jp

Received 30 August 2011; Revised 25 October 2011; Accepted 25 October 2011

Academic Editor: Karim A. Alkadhi

Copyright (c) 2012 Tamotsu Imanishi et al. This is an open access article distributed under the Creative Commons Attribution License, which permits unrestricted use, distribution, and reproduction in any medium, provided the original work is properly cited.

Anticholinesterases (antiChEs) are used to treat Alzheimer's disease. The comparative effects of two antiChEs, methanesulfonyl fluoride (MSF) and donepezil, on the extracellular levels of ACh in the hippocampus were investigated by in vivo microdialysis in freely moving rats. MSF at 1 and $2 \mathrm{mg} / \mathrm{kg}$ produced a dose-dependent increase in ACh efflux from $10 \mathrm{~min}$ to at least $3 \mathrm{hrs}$ after injection. At $2 \mathrm{mg} / \mathrm{kg}$, the increase was still present at $24 \mathrm{hr}$. Donepezil at $1 \mathrm{mg} / \mathrm{kg}$ showed a similar but smaller effect, and, paradoxically, $2 \mathrm{mg} / \mathrm{kg}$ showed no consistent effect. MSF at 1 and $2 \mathrm{mg} / \mathrm{kg}$ decreased acetylcholinesterase activity in the hippocampus to 54.8 and $20.1 \%$ of control, respectively. These results suggest that MSF is a suitable candidate for the treatment of Alzheimer's disease.

\section{Introduction}

Alzheimer's disease $(\mathrm{AD})$ is a slowly progressive neurodegenerative illness characterized by the presence of senile plaques containing $\beta$-amyloid protein $(\mathrm{A} \beta)$ in brain tissue, tau-neurofibrillary tangles in neurons and, the loss of different transmitter-containing axons, especially cholinergic nerves $[1,2]$. Unfortunately, therapeutic strategies targeting amyloid plaques with plaque-removing vaccines or gammasecretase modulators have been disappointing $[3,4]$.

It is generally accepted that progressive neurodegeneration of the cholinergic system underlies, at least in part, the cognitive deterioration of Alzheimer's disease (AD) [57]. This hypothesis is supported by findings of encouraging symptomatic improvements in clinical trials by the use of
AChE inhibitors $[8,9]$, theoretically by enhancing central cholinergic function by permitting acetylcholine (ACh) to remain in the synaptic cleft longer. Interestingly, some AChE inhibitors have also been reported to be effective also in diminishing amyloid plaques $[10,11]$.

Methanesulfonyl fluoride (MSF), a long-acting and highly specific inhibitor of brain AChE $[12,13]$, has been proposed as a safe and effective palliative treatment for senile dementia of the Alzheimer type [14] as well as a method to attenuate stroke-induced deficits in a simple learning and memory task [13]. Therefore, the main aim of this study was to compare MSF-induced increases in extracellular ACh in the hippocampus, one of the target regions for the treatment of $\mathrm{AD}$, with the effects of donepezil, a reference drug widely used for symptomatic treatment of AD. For this purpose, the 
present study was carried out by measuring extracellular ACh in the hippocampus by in vivo microdialysis in freely moving rats following administration of MSF and donepezil.

\section{Materials and Methods}

Male Sprague-Dawley rats (Japan SLC, Hamamatsu, Japan) weighting 200-250 g were housed one per cage under the standard laboratory conditions $\left(23 \pm 1^{\circ} \mathrm{C}, 55 \pm 5 \%\right.$ humidity) with free access to standard pellet diet (MEQ, Oriental Yeast Co., Tokyo) and drinking water ad libitum with lights on at 08:00 and off at 20:00. Animal handling and procedures were conducted in accordance with the Animal Welfare Act and with the Guide for the Care and Use of Laboratory Animals approved by the Animal Experiment Committee in Iwate University, Japan. Five rats were used in each group.

All reagents used were analytical grade. MSF was purchased from Sigma-Aldrich (Milwaukee, USA) and $(R, S$ 1-benzyl-4-[(5,6-dimethoxy-1-indanon-2-yl)] methylpiperidine hydrochloride (donepezil) was a gift from Eisai Co., Ltd., (Tokyo, Japan).

Microdialysis experiments were conducted according to Hossain et al. [15]. Briefly, the rats were anesthetized with sodium pentobarbital $(50 \mathrm{mg} / \mathrm{kg}$, i.p.) and then placed in a stereotaxic apparatus (Kopf instrument). The microdialysis guide cannula (AG-8, Eicom, Kyoto, Japan) was implanted into the left hippocampus with the following coordination (from the bregma): A $-5.8 \mathrm{~mm}, L+4.8 \mathrm{~mm}$ and, $\mathrm{V}-4.5$ $\mathrm{mm}$. Following surgery, the animals were returned to their home cage and allowed to recover for at least 3 days before the beginning microdialysis.

ACh and choline content in the dialysate from the different animals were quantified by high-performance liquid chromatograph (HPLC) with electrochemical detection (ECD). The day of the experiment, the microdialysis probe (A-1-8-02, Eicom, Kyoto) was carefully inserted into the hippocampus through the guide cannula. The inlet of the microdialysis probe was connected to a $2.5 \mathrm{~mL}$ gastight syringe and perfused with Ringer's solution $(\mathrm{NaCl} 147 \mathrm{mM}$, $\mathrm{KCl} 4.0 \mathrm{mM}$ and, $\mathrm{CaCl}_{2} 2.3 \mathrm{mM}$ ) containing $1 \mu \mathrm{M}$ eserine salicylate at a constant flow $2 \mu \mathrm{L} / \mathrm{min}$ using a microperfusion pump, allowing the rats to move freely in a cubic Plexiglas box $(30 \mathrm{~cm} \times 30 \mathrm{~cm} \times 40 \mathrm{~cm})$.

The dialysate collected during the first $30 \mathrm{~min}$ was discarded to ensure a stable baseline of ACh release. Thereafter, $20 \mu \mathrm{L}$ samples of perfusate were collected at $10 \mathrm{~min}$ intervals. Upon collection, $20 \mu \mathrm{L}$ of $1 \mu \mathrm{M}$ ethylhomocholine containing $10 \mathrm{mM}$ EDTA $2 \mathrm{Na}$ was added to each sample as an internal standard. Levels of ACh and choline in the dialysate $(20 \mu \mathrm{L} /$ injection $)$ were determined by electrochemical detection with HPLC (Eicom, Kyoto, Japan) equipped with an enzyme column (AC-ENZ, Eicom, Kyoto, Japan). A $20 \mu \mathrm{L}$ sample of the perfusate/ethylhomocholine solution was then injected into a HPLC equipped with ECD (HPLCECD, Eicom, Kyoto) and enzyme column (AC-ENZ, Eicom, Kyoto).

ACh and choline were separated on a cation exchange column (EICOMPAK AC-GEL, Eicom, Kyoto) with sodium lauryl sulfate $(0.5 \mathrm{mg} / \mathrm{mL})$. The mobile phase consisted of $0.05 \mathrm{M}$ phosphate buffer $\left(\mathrm{Na}_{2} \mathrm{HPO}_{4} \quad 12 \mathrm{H}_{2} \mathrm{O}\right) \mathrm{pH} 8.2$ containing $0.13 \mathrm{mM}$ EDTA $2 \mathrm{Na}, 0.6 \mathrm{mM}$ tetramethylammonium chloride and, $1.2 \mathrm{mM}$ SDS pumped at $1 \mathrm{~mL} / \mathrm{min}$. The retention times for choline and ACh were 7.3 and $13.2 \mathrm{~min}$, respectively.

The basal efflux was defined as the average output of three samples prior to drug administration, and the results were calculated as the percentage of the baseline choline and ACh.

After establishing the basal efflux, the animals received one of the following IP injections: MSF ( 1 or $2 \mathrm{mg} / \mathrm{kg}$ ) or donepezil ( 1 or $2 \mathrm{mg} / \mathrm{kg}$ ) dissolved in vehicle $(80 \mu \mathrm{L}$ ethanol $+88 \mu \mathrm{L}$ Tween 20) and prepared to a $1 \mathrm{~mL}$ total volume with isotonic sodium chloride. All control animals were injected with the same isotonic sodium chloride/vehicle solution by the same route and volume $(1 \mathrm{~mL} / \mathrm{kg})$ as the drug.

At the end of the microdialysis experiment, the rats were euthanized with chloroform, the brains were removed, and the position of the probe in the hippocampus was verified by visual examination of $20 \mu \mathrm{m}$ frozen sections.

For acetylcholinesterase assays, rats in a parallel group received the same injections of MSF, donepezil, or vehicle on the same schedule as the animals used in microdialysis experiment. Three brain regions, hippocampus, striatum, and cerebral cortex (cortex) were quickly dissected on ice at $180 \mathrm{~min}$ and $24 \mathrm{hr}$ after injection of MSF or donepezil and then homogenized in $0.1 \mathrm{M}$ phosphate buffer solution $(0.1 \mathrm{M}$ $\mathrm{Na}_{2} \mathrm{PO}_{4}+0.1 \mathrm{M} \mathrm{KH}_{2} \mathrm{PO}_{4}, \mathrm{pH} 8.0$ ), followed by dilution with the same buffer to 200, 400, and 200 times of tissue weight, respectively, for the analysis of $\mathrm{AChE}$ activity by the method of Ellman et al. [16] with $0.48 \mathrm{mM}$ acetylthiocholine iodide as substrate for $2 \mathrm{~min}$ at $25^{\circ} \mathrm{C}$ using UV-240 spectrophotometer (Shimadzu Corporation, Kyoto, Japan) at $412 \mathrm{~nm}$.

The extracellular levels of $\mathrm{ACh}$ and choline from individual rats were calculated relative to the mean basal release (the average of three 10 min sequential samples before drug administration was taken as $100 \%$ basal release). Analysis of variance, followed by Dunnett's post hoc test for repeated measurements (treatment versus time), was used to analyze changes from ACh and choline baselines as well as for tests of significant differences over time. A level of $P<0.05$ was taken to indicate a statistically significant effect.

\section{Results}

The injections of MSF and donepezil (1 and $2 \mathrm{mg} / \mathrm{kg}$ i.p.) did not produce any observable clinical signs or symptoms in the rats. The basal rates of efflux from the hippocampus of vehicle-only injected control rats were $5.2 \pm 0.2 \mathrm{pmol} \mathrm{ACh} / 10 \mu \mathrm{L} / 10 \mathrm{~min}$ and $180.8 \pm 2.6 \mathrm{pmol}$ choline $/ 10 \mu \mathrm{L} / 10 \min (n=15)$. The response of ACh in the hippocampus to vehicle treatment was not significantly different throughout the experiment.

As shown in Figure 1, MSF increased the release of ACh in a dose-dependent manner. MSF, at $1 \mathrm{mg} / \mathrm{kg}$, caused a significant $(P<0.05, P<0.01)$ and prolonged increase of 


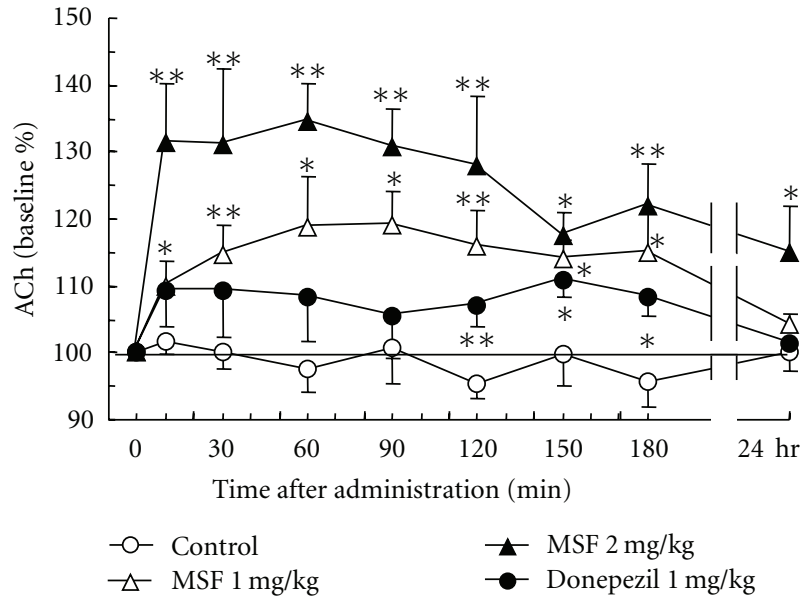

FIGURE 1: Effect of MSF and donepezil on the level of extracellular $\mathrm{ACh}$ in the freely moving rats. Data are expressed as percentage changes from baseline. Each value represents the mean \pm S.E.M. of five experiments. Asterisks indicate effects significantly different from time course vehicle control $\left({ }^{*} P<0.05,{ }^{* *} P<0.01\right)$.

ACh efflux in the hippocampus from 10 to 180 min which returned to control levels at $24 \mathrm{hr}$ after the administration of MSF. At the higher dose of $2 \mathrm{mg} / \mathrm{kg}$, MSF produced a consistent and proportionately larger increase in ACh release between 10 to $90 \mathrm{~min}(P<0.01)$, decreasing progressively from 120 to $180 \mathrm{~min}(P<0.05, P<0.01)$ after the treatment. At $2 \mathrm{mg} / \mathrm{kg}$ MSF, the elevation of ACh efflux remained elevated at $24 \mathrm{hr}$ after injection $(P<0.05)$.

The effects of donepezil on ACh efflux are also shown in Figure 1. A dose of $1 \mathrm{mg} / \mathrm{kg}$ donepezil produced a small but consistent increase in ACh efflux over the first 180 minutes. However, the dose of $2 \mathrm{mg} / \mathrm{kg}$ did not produce a dose-dependent effect, and ACh efflux over the $180 \mathrm{~min}$ experiment was not different from animals received the dose of $1 \mathrm{mg} / \mathrm{kg}$ (data not shown).

As shown in Figure 2, the choline efflux decreased progressively from basal levels throughout the course of the first 180 min after injection for every group, MSF, donepezil, and controls but returned to basal levels by $24 \mathrm{hr}$. The decreases were less significant in the groups that received MSF or donepezil than in the control group.

The effect of MSF and donepezil on AChE activity in the hippocampus, striatum, and cortex at $180 \mathrm{~min}$ (Figure 3(a)) and $24 \mathrm{hr}$ (Figure 3(b)) after drug administration is shown in Figure 3. MSF at $1 \mathrm{mg} / \mathrm{kg}$ decreased AChE activity in hippocampus, striatum, and cortex by about $50 \%$, to 55 , 51 , and $49 \%$ of the respective control activities. At $2 \mathrm{mg} / \mathrm{kg}$, MSF produced $80-90 \%$ inhibition, bringing AChE activity to about 20,12 , and $11 \%$ of the respective control activities. Donepezil at $1 \mathrm{mg} / \mathrm{kg}$ did not produce any significant effect on AChE activity in the three brain regions at $180 \mathrm{~min}$ after injection. The dose of $2 \mathrm{mg} / \mathrm{kg}$, however, produced a significant decrease in AChE activity in the cortex but not in the hippocampus or striatum $180 \mathrm{~min}$ after administration (Figure 3(a)). Figure 3(b) also shows the brain regional AChE activity $24 \mathrm{hr}$ after $1 \mathrm{mg} / \mathrm{kg}$ of MSF or donepezil. The

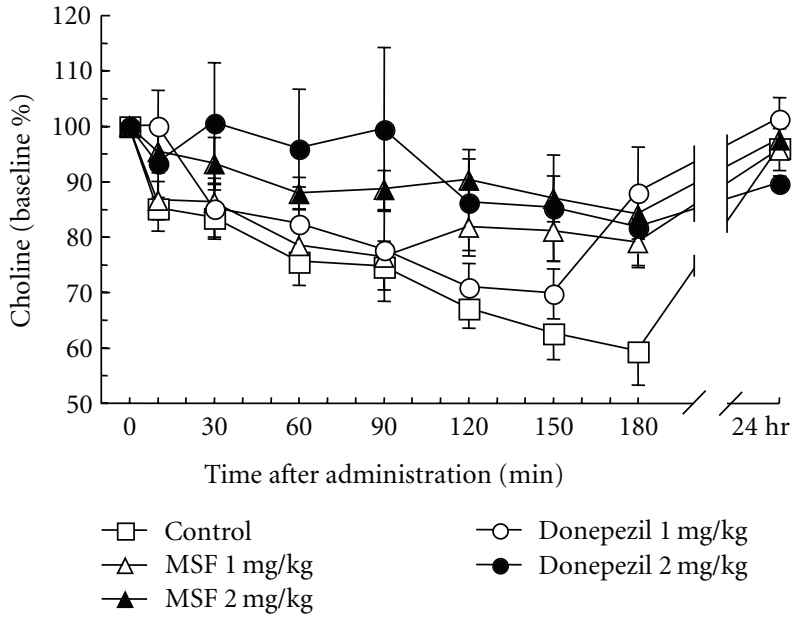

FIGURE 2: Effect of MSF and donepezil on the level of extracellular choline in the freely moving rats. Data are expressed as percentage changes from baseline. Each value represents the mean \pm S.E.M. of five experiments.

activity of AChE in the hippocampus, striatum, and cortex of rats administered MSF was about 44,36 and $41 \%(P<0.05$ to 0.001 ) of control values, respectively. At $24 \mathrm{hr}$, no other significant differences were not observed in the activity of $\mathrm{AChE}$ in any of the three brain regions between the rats treated with donepezil or vehicle.

\section{Discussion}

We have previously reported that a single dose of MSF at $1.5 \mathrm{mg} / \mathrm{kg}$ s.c. significantly increased the concentrations of extraterminal ACh and cytoplasmic ACh in the cortex of mice [17]. In these experiments, an increase in the fractional ACh content of brain tissues taken ex vivo and homogenized for analysis was found to be elevated at $180 \mathrm{~min}$, and the increase persisted to $24 \mathrm{hr}$. The extraterminal ACh determined in that earlier ex vivo experiment may approximately correspond to extracellular ACh in the current in vivo experiment at those same time points. The present experiment confirmed the earlier results and showed that doses of either $1 \mathrm{mg} / \mathrm{kg}$ or $2 \mathrm{mg} / \mathrm{kg}$ MSF strongly increase extracellular ACh during the first $180 \mathrm{~min}$ after administration and the effect persists for $24 \mathrm{hr}$ after the higher dose of $2 \mathrm{mg} / \mathrm{kg}$.

Corresponding to the increases in ACh efflux found after MSF, the present study also found that the same doses reduced AChE activity in the hippocampus to about 55\% and $20 \%$ of control $180 \mathrm{~min}$ after $1 \mathrm{mg} / \mathrm{kg}$ and $2 \mathrm{mg} / \mathrm{kg}$ of MSF, respectively, and to about $44 \%$ of control $24 \mathrm{hr}$ after $1 \mathrm{mg} / \mathrm{kg}$ of MSF (the only dose studied at $24 \mathrm{hr}$ ). These results support several studies on the effects of drugs for Alzheimer's disease that show that increasing levels of extracellular ACh in various brain regions are found with decreasing $\mathrm{AChE}$ activity $[8,9,18-22]$.

Donepezil $(1.66 \mathrm{mg} / \mathrm{kg})$, rivastigmine $(0.4 \mathrm{mg} / \mathrm{kg})$, and huperzine A (more than 0.6 and $3 \mathrm{mg} / \mathrm{kg}$ ) have been found to increase extracellular ACh in the hippocampus, and the 


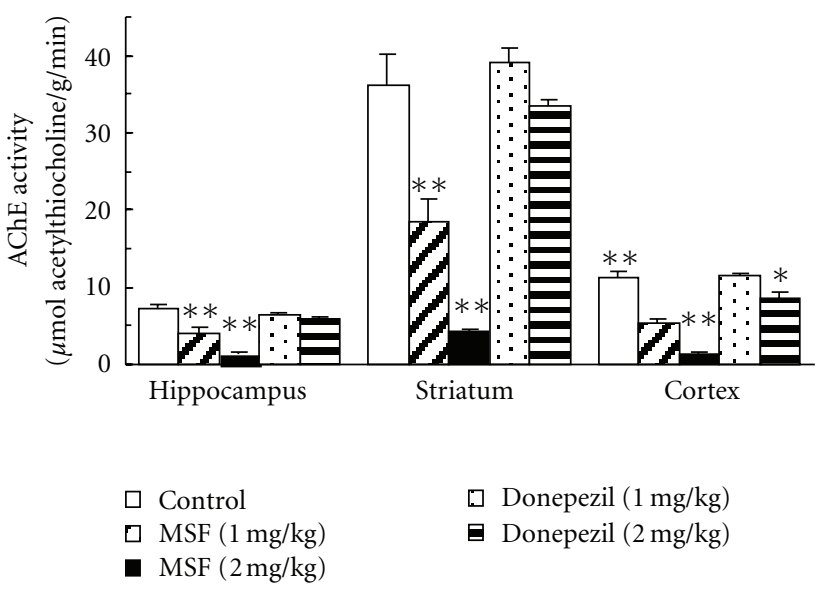

(a)

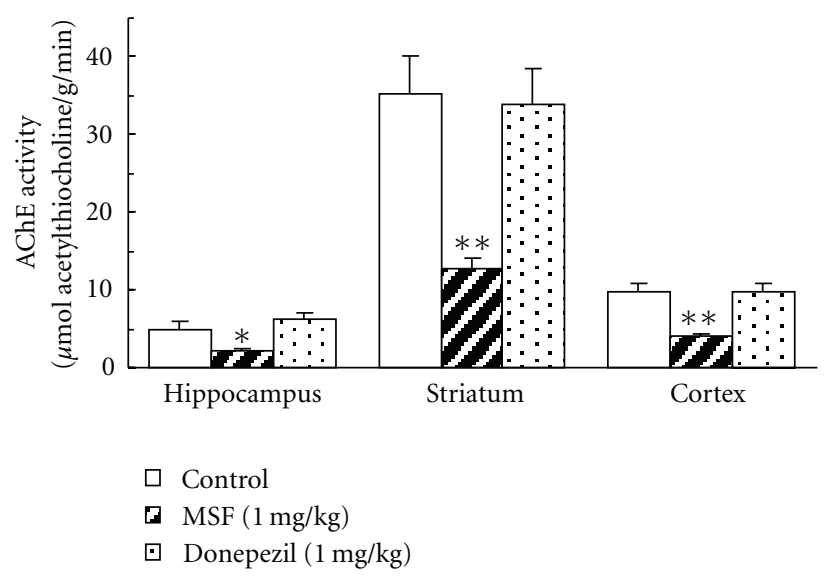

(b)

FIGURE 3: Effect of MSF and donepezil on the activity of AChE in brain regions $180 \mathrm{~min}$ (a) and $24 \mathrm{hr}$ (b) after administration. Each value represents the mean \pm S.E.M. of five experiments. Asterisks indicate effects significantly different from time course vehicle control $\left({ }^{*} P<0.05\right.$, ** $P<0.01)$.

results are generally not so different between the oral or intraperitoneal administration $[8,18]$. All three of these drugs produced the maximal increase in extracellular ACh within $3 \mathrm{hrs}$, mostly around 30 to $60 \mathrm{~min}$, after administration. On the other hand, the present study shows that MSF increased the level of extracellular ACh for at least $3 \mathrm{hrs}$ without showing significant peaks. After $2 \mathrm{mg} / \mathrm{kg}$ MSF, a significant increase was still present at $24 \mathrm{hr}$.

Although donepezil is generally accepted to be effective in increasing the release of ACh from hippocampus in freely moving animals $[8,9]$, the present study, however, found that donepezil succeeded in increasing extracellular ACh only at a dose of $1 \mathrm{mg} / \mathrm{kg}$. Surprisingly, it failed to demonstrate a dose-dependent effect at a dose of $2 \mathrm{mg} / \mathrm{kg}$. Although the doses of donepezil, $1 \mathrm{mg} / \mathrm{kg}$ and $2 \mathrm{mg} / \mathrm{kg}$, were selected for comparison to the MSF results, a possible explanation for our failure to find a dose-dependent effect of donepezil on extracellular ACh may be that the dose of $2 \mathrm{mg} / \mathrm{kg}$ was not sufficiently greater than the $1 \mathrm{mg} / \mathrm{kg}$ dose to produce a clear difference. The dose-dependent effects of donepezil on increasing the level of extracellular ACh in the striatum achieved by previous reports [18] were obtained by using doses at 1,3 , and $5 \mathrm{mg} / \mathrm{kg}$.

In the present study, donepezil at doses of 1 and $2 \mathrm{mg} / \mathrm{kg}$ did not show any significant inhibitory effect on the activity of AChE in the hippocampus at $180 \mathrm{~min}$ after administration (Figure 3(a)). Donepezil is a reversible AChE inhibitor [9, 23 ] and the AChE inhibition it produces may disappear when the tissues are homogenized as the donepezil will be diluted.

\section{Conclusions}

The present study showed that MSF at doses 1 and $2 \mathrm{mg} / \mathrm{kg}$ produced a consistent increase in the efflux of ACh in freely moving rats as measured by microdialysis throughout the first $3 \mathrm{hrs}$ at both doses and a persistent increase was still present at $24 \mathrm{hr}$ at the higher dose. Since ChE inhibitors are the major therapeutic agents used in $\mathrm{AD}$ patients, the agent-like MSF, which increases extracellular ACh in the hippocampus with a long-lasting efficacy but without excess stimulation, may serve as an effective therapy to alleviate or prevent the central cholinergic deficits which are reported to cause cognitive impairments.

\section{Acknowledgment}

The authors would like to thank Dr. Moss, D.E., Department of Psychology, University of Texas at El Paso, USA. for reviewing the paper and valuable suggestions.

\section{References}

[1] H. Braak and E. Braak, "Neuropathological stageing of Alzheimer-related changes," Acta Neuropathologica, vol. 82, no. 4, pp. 239-259, 1991.

[2] D. R. Thal, U. Rüb, M. Orantes, and H. Braak, "Phases of $\mathrm{A} \beta$-deposition in the human brain and its relevance for the development of AD," Neurology, vol. 58, no. 12, pp. 17911800, 2002.

[3] P. E. Potter, "Investigational medications for treatment of patients with Alzheimer disease," Journal of the American Osteopathic Association, vol. 110, supplement 8, pp. S27-S36, 2010.

[4] D. W. Ethell, "An amyloid-notch hypothesis for Alzheimer's disease," Neuroscientist, vol. 16, no. 6, pp. 614-617, 2010.

[5] P. Davies and A. J. F. Maloney, "Selective loss of central cholinergic neurons in Alzheimer's disease," The Lancet, vol. 2, no. 8000, p. 1403, 1976.

[6] E. J. Mufson, A. D. Kehr, B. H. Wainer, and M. M. Mesulam, "Cortical effects of neurotoxic damage to the nucleus basalis in rats: persistent loss of extrinsic cholinergic input and lack of transsynaptic effect upon the number of somatostatincontaining, cholinesterase-positive, and cholinergic cortical neurons," Brain Research, vol. 417, no. 2, pp. 385-388, 1987.

[7] P. J. Whitehouse, D. L. Price, A. W. Clark, J. T. Coyle, and M. R. DeLong, "Alzheimer disease: evidence for selective 
loss of cholinergic neurons in the nucleus basalis," Annals of Neurology, vol. 10, no. 2, pp. 122-126, 1981.

[8] Y. Q. Liang and X. C. Tang, "Comparative studies of huperzine A, donepezil, and rivastigmine on brain acetylcholine, dopamine, norepinephrine, and 5-hydroxytryptamine levels in freely-moving rats," Acta Pharmacologica Sinica, vol. 27, no. 9, pp. 1127-1136, 2006.

[9] H. Sugimoto, H. Ogura, Y. Arai, Y. Iimura, and Y. Yamanishi, "Research and development of donepezil hydrochloride, a new type of acetylcholinesterase inhibitor," Japanese Journal of Pharmacology, vol. 89, no. 1, pp. 7-20, 2002.

[10] M. Rosini, E. Simoni, M. Bartolini et al., "Inhibition of acetylcholinesterase, $\beta$-amyloid aggregation, and NMDA receptors in Alzheimer's disease: a promising direction for the multi-target-directed ligands gold rush," Journal of Medicinal Chemistry, vol. 51, no. 15, pp. 4381-4384, 2008.

[11] H. Sugimoto, "The new approach in development of antiAlzheimer's disease drugs via the cholinergic hypothesis," Chemico-Biological Interactions, vol. 175, no. 1-3, pp. 204-208, 2008.

[12] D. E. Moss, H. Kobayashi, G. Pacheco, R. Paracios, and R. G. Perez, "Methanesulfonyl fluoride: a CNS selective inhibitor," in Current Research in Alzheimer Theory: Cholinesterase Inhibitors, E. Giacobini and R. Becher, Eds., pp. 305-314, Taylor and Francis, New York, NY, USA, 1988.

[13] G. Pacheco, R. Palacios-Esquivel, and D. E. Moss, "Cholinesterase inhibitors proposed for treating dementia in Alzheimer's disease: selectivity toward human brain acetylcholinesterase compared with butyrylcholinesterase," Journal of Pharmacology and Experimental Therapeutics, vol. 274, no. 2, pp. 767-770, 1995.

[14] D. E. Moss, P. Berlanga, M. M. Hagan, H. Sandoval, and C. Ishida, "Methanesulfonyl fluoride (MSF): a double-blind, placebo-controlled study of safety and efficacy in the treatment of senile dementia of the Alzheimer type," Alzheimer Disease and Associated Disorders, vol. 13, no. 1, pp. 20-25, 1999.

[15] M. M. Hossain, T. Suzuki, I. Sato, T. Takewaki, K. Suzuki, and H. Kobayashi, "The modulatory effect of pyrethroids on acetylcholine release in the hippocampus of freely moving rats," NeuroToxicology, vol. 25, no. 5, pp. 825-833, 2004.

[16] G. L. Ellman, K. D. Courtney, V. Andres, and R. M. Featherstone, "A new and rapid colorimetric determination of acetylcholinesterase activity," Biochemical Pharmacology, vol. 7, no. 2, pp. 88-95, 1961.

[17] H. Kobayashi, T. Nakano, D. E. Moss, and T. Suzuki, "Effects of a central anticholinesterase, methanesulfonyl fluoride on the cerebral cholinergic system and behavior in mice: comparison with an organophosphate DDVP," Journal of Health Science, vol. 45, no. 4, pp. 191-202, 1999.

[18] K. Isomae, M. Ishikawa, M. Ohta et al., "Effects of T82, a new quinoline derivative, on cholinesterase activity and extracellular acetylcholine concentration in rat brain," Japanese Journal of Pharmacology, vol. 88, no. 2, pp. 206-212, 2002.

[19] T. Kosasa, Y. Kuriya, and Y. Yamanishi, "Effect of donepezil hydrochloride (E2020) on extracellular acetylcholine concentration in the cerebral cortex of rats," Japanese Journal of Pharmacology, vol. 81, no. 2, pp. 216-222, 1999.

[20] E. Shearman, S. Rossi, B. Szasz et al., "Changes in cerebral neurotransmitters and metabolites induced by acute donepezil and memantine administrations: a microdialysis study," Brain Research Bulletin, vol. 69, no. 2, pp. 204-213, 2006.
[21] K. Takashina, T. Bessho, R. Mori, J. Eguchi, and K. I. Saito, "MKC-231, a choline uptake enhancer: (2) Effect on synthesis and release of acetylcholine in AF64A-treated rats," Journal of Neural Transmission, vol. 115, no. 7, pp. 1027-1035, 2008.

[22] K. Yano, K. Koda, Y. Ago et al., "Galantamine improves apomorphine-induced deficits in prepulse inhibition via muscarinic ACh receptors in mice," British Journal of Pharmacology, vol. 156, no. 1, pp. 173-180, 2009.

[23] M. Živin and P. Pregelj, "Prolonged treatment with donepezil increases acetylcholinesterase expression in the central nervous system," Psychiatria Danubina, vol. 20, no. 2, pp. 168173, 2008. 

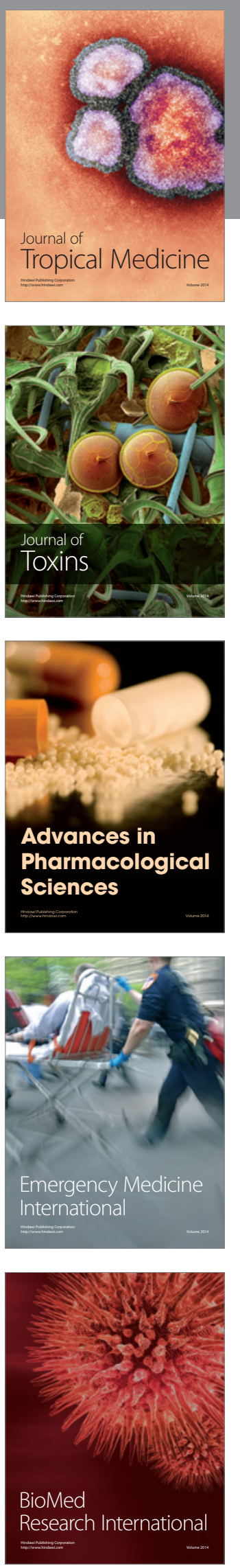
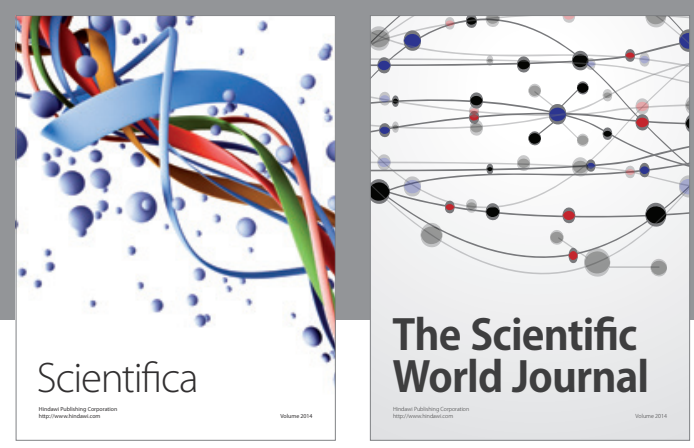

The Scientific World Journal
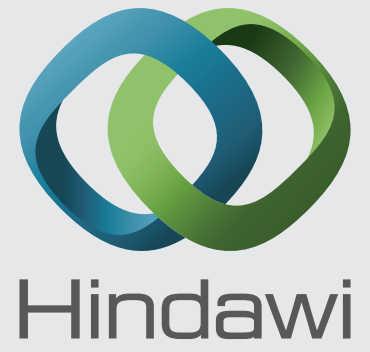

Submit your manuscripts at

http://www.hindawi.com
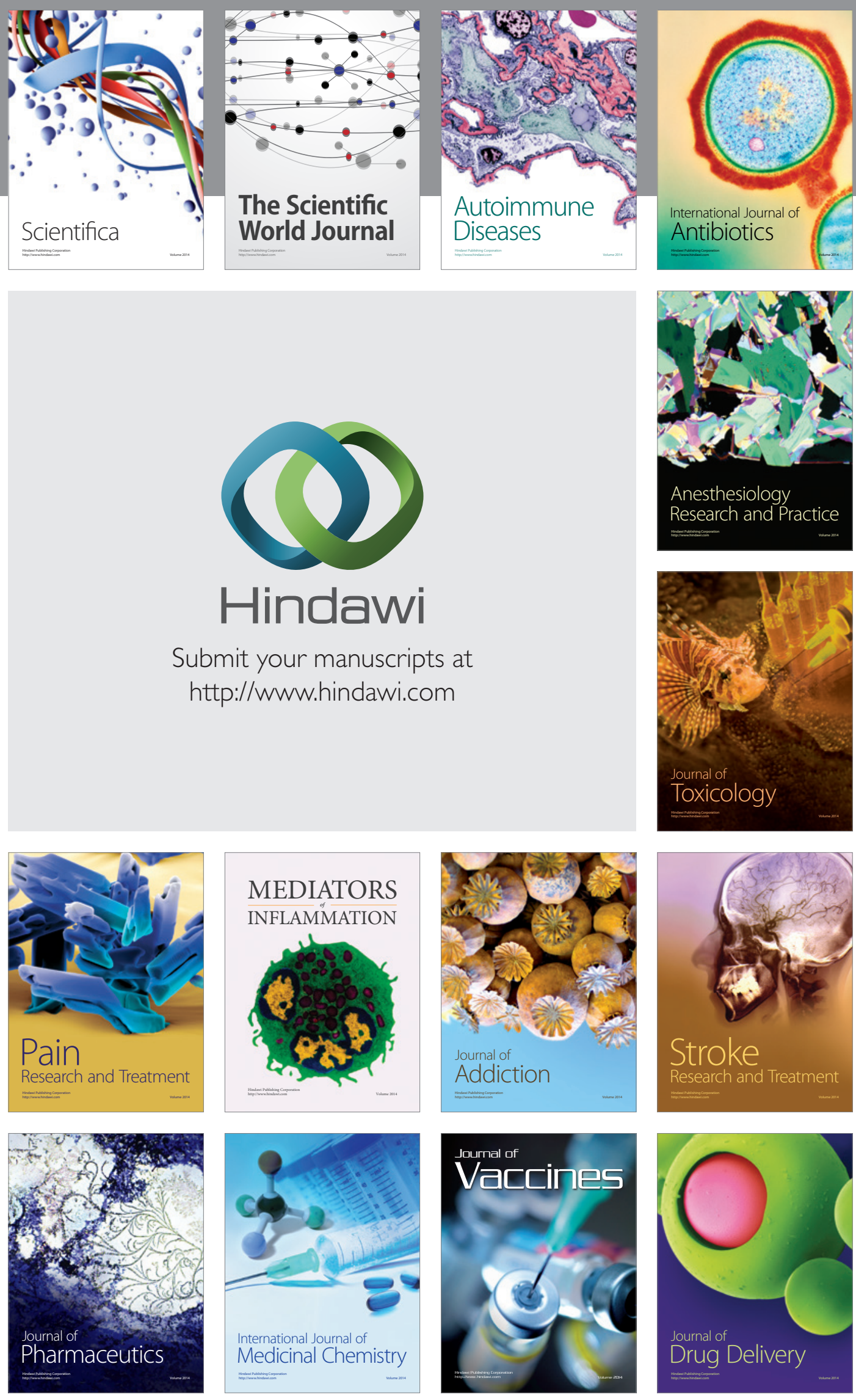